\title{
PTC ヒーターを用いた電気床暖房の制御システムの構築及び実験 オフセットの除去を目的とした室温の最適制御手法の構築 \\ DEVELOPMENT AND EXPERIMENTAL EVALUATION OF A CONTROL SYSTEM FOR A PTC FLOOR HEATING SYSTEM
}

Optimal control of the PTC floor heating system to remove the room temperature offset

\author{
萬成恵佐**, 浅野良晴*, 高村秀紀***
}

\section{Keisuke MANNARI, Yoshiharu ASANO and Hideki TAKAMURA}

\begin{abstract}
This research concerns a room temperature control experiment using a PTC floor heating system. It aims at development of control techniques for the PTC heater in the room, which is assumed to be part of a house. In this report, a control technique taking into account the heating load was developed based on the PI control technique in order to remove the room temperature offset. As a result, the offset was removed and it was shown clearly that PI control is effective as a control technique for a PTC floor heating system.
\end{abstract}

Keywords : control, Positive Temperature Coefficient, floor heating, offset, experiment with a model 制御，PTC，床暖房，オフセット，模型実験

\section{1.はじめに}

\section{1 研究背景}

床暖房は伝導と輻射による熱移動で、人や部屋を暖める暖房方式 である。空調などによる対流式暖房に比べ、上下の温度差が少なく 頭寒足熱による熱的快適性が高いと言われている ${ }^{1) 2) 。 ~}$

三垣ら ${ }^{3)}$ や稲葉ら ${ }^{4)}$ は潜熱蓄熱式電気床暖房と空調機を併用し、 SET*を空調制御のパラメータとし、時系列変動する加熱負荷に対応 した制御方法を構築した。稲葉ら ${ }^{5)}$ や浜口ら ${ }^{6)}$ によ夜間に蓄熱を 行い、日中に放熱を行う潜熱蓄熱式電気床暖房は、高齢者施設や才 フィスで有効な暖房方法であることが確認されている。さらに、三 浦ら ${ }^{7)}$ や吉浦ら ${ }^{8)}$ により蓄熱式及び温水式の床暖房の制御に関する 研究が報告されている。

床暖房の方式の一つに非蓄熱材である PTC ヒーターを用いたもの がある。PTC とはPositive Temperature Coefficient の略であり、 本研究ではこれを用いる。一般に、温度上昇に伴って特定の物理量 が増大寸る特性を PTC 特性と呼ぶ。本研究で扱う PTC 特性は発熱体 固有の温度に近づくと導体の電気抵抗が急激に増大し、それ以降の 温度上昇が抑制されて一定の発熱温度を持続するものであり、自己 温度制御特性とも呼ばれる。このPTC ヒーターの有する自己温度制 御特性により、床暖房に使用した場合は、オーバーヒートや閉塞温 度の過上昇が防止され、省エネルギー性及び安全性を高めることが 出来る。PTC ヒーターの特性に関しては小林ら ${ }^{9)}$ や占部ら ${ }^{10)}$ が報告
しているが、一方でその制御方法に関する報告は未だ少ない。 住宅の床暖房として、この自己温度制御特性を利用した床暖房が ある。2005 年に電気床暖房工業会（JEF）が自己過熱抑制 PTC 電気 床暖房の製品の安全性の確保を目的として自主基準を制定した。

精密な温度制御を行うものとして PID 制御がある。PID 制御は偏 差に比例した出力を出す比例動作、偏差の時間積分に比例した出力 を出す積分動作、偏差の時間的変化率に比例した出力を出す微分動 作の 3 動作を同時に行う制御である。PID 制御は火力発電所におけ るボイラの過熱蒸気温度の制御 ${ }^{11)}$ 、モーター駆動の制御 ${ }^{12}{ }^{13)}$ 、ク レーンのつり荷の振れ止め制御 ${ }^{14)}$ 、倒立振子制御 ${ }^{15)}$ に用いられ、 機械システムや化学プラントなどの実システムにおいてはPID 制御 が今なお多く用いられているのが現状である。

PID 制御の建築分野への応用としては Kasahara ${ }^{16)}$ 17) や國吉 ${ }^{18)} 、$ 前原 ${ }^{19)}$ 、松岡 ${ }^{20)}$ 、丹羽 ${ }^{21)}$ らによる HVAC (Heating, Ventilating and Air Conditioning : 冷暖房空調設備) やVAV (Variable Air Volume : 可変風量）などの空調システムに関する研究がある。

\section{2 研究目的}

本研究の目的は、PTC ヒーターを住宅の床暖房として適用する場 合のオフセットの除去の観点から分析を行い、モデル化に当たって 生じた問題を明らかにすると共に、PTC ヒーターによる住宅の床暖 房においてオフセットの除去を達成する制御方法を提案するもので ある。

\footnotetext{
* 信州大学工学部建築学科, 信州大学山岳科学総合研究所 教授・ 工博

** 前田建設工業侏) 修士(工学) (研究当時大学院生)

*** 信州大学工学部建築学科, 信州大学山岳科学総合研究所 助教・博士 (工学)
}

Prof., Dept. of Architecture, Faculty of Eng., Univ. of Shinshu and Institute of Mountain Science, Univ. of Shinshu, Dr. Eng.

Maeda Corporation, M. Eng.

Assistant Prof., Dept. of Architecture, Faculty of Eng., Univ. of Shinshu and Institute of Mountain Science, Univ. of Shinshu, Dr. Eng. 
PTC ヒーターの普及はここ 10 年のことでありながら、その制御方 法として一般的な方法は、リレーの切り替えによる On-Off 制御であ る。空調機などにおける室内温度制御として更に優れた方法がある にも関わらず、PTC ヒーターの制御方法として On-Off 制御を用いて いる理由は、PTCヒーターの持つPTC 特性にある。

PTC ヒーターは、PTC 特性という温度上昇に伴って特定の物理量が 増大する特性を持つ。この PTC ヒーターの持つ PTC 特性はそのまま 制御の困難さに繋がる。PTC ヒーターの持つPTC 特性は温度上昇に 伴い抵抗值を上昇させるものである。すなわち、一定の電圧に対す る発熱量が一定にならず、目標とする発熱量を得ることが出来ない。 そのことが、PTCヒーターの一般的な制御に電圧や抵抗值に関わら ず制御できる On-Off 制御が用いられている理由である。

目標とする発熱量を得られないことは、室内の温熱快適性及び省 エネルギー性の面からも避けられるべきであることは明らかである。 また、筆者の既往の研究によって ON-Off 制御では目標温度帯におけ る上限值で電力投入を止め、下限值で電力投入を始めるといったプ ロセスを繰り返すことから室温の変動が大きくなり、室内の温熱快 適性の面から制御方法として最適でないことを明らかにした。

そのことから、筆者は電圧制御による PTC ヒーターの最適制御手 法の構築を試みた。温度上昇に伴い変動する抵抗值に関わらず目標 とする発熱量を得るために、電圧を制御することにより目標とする 発熱量を得ようとする試みである。

まず、筆者は比例（P）制御による室内温度制御を行った。筆者の 既往の研究により、比例制御では時系列変動する加熱負荷、寸なわ ち外気温度の変動による熱損失及び人体・設備機器による内部発熱 の熱取得に追随することは確認出来たが、オフセット（定常偏差） が発生することが明らかになった。

負荷に追随し、室温を目標温度に一致させるために、PTC ヒータ 一から一定の発熱量を得るためにはオフセットを除去する必要があ る。そこで、本研究ではオフセット除去による室温の最適制御手法 の構築を目的とし、PTC ヒーターを床暖房として適用する場合にオ フセットに影響を及ぼす項目を明確にし、制御システムをモデル化 することによりオフセット除去の有効性を検証し、実験によりオフ セット除去の有効性を検証している。

\section{2. 床暖房の加熱制御}

本研究で扱う PTC 床暖房の制御方法は On-Off 制御、比例制御、比 例積分制御の 3 つである。On-Off 制御は前章で述べたように室温の 変動が大きい。比例制御の内容を（1）式で表す。

$$
\begin{aligned}
& M V=K p \times e+Q p \quad \cdots(1) \\
& \text { ただし、 } e=T t-T r \quad \cdots(2)
\end{aligned}
$$

(1) 式では $T t$ と $T r$ が等しくなり $e=0$ となった場合に、固定值 である $Q p$ が残り、PTC ヒーターから一定量の発熱がある。そして、 $T o$ 及び $P i$ の変動により $T t$ における加熱負荷が変動するのに対し、 PTC ヒーターの Tt における発熱量が一定であるためオフセットが 発生する。

加熱負荷とは、室温が目標温度に達した状態において、室温と外 気温度との温度差より算出した損失熱量から、内部発熱による取得 熱量を差し引いた值とする。

実験モデルにおける熱取得は PTC ヒーターからの発熱及び内部発

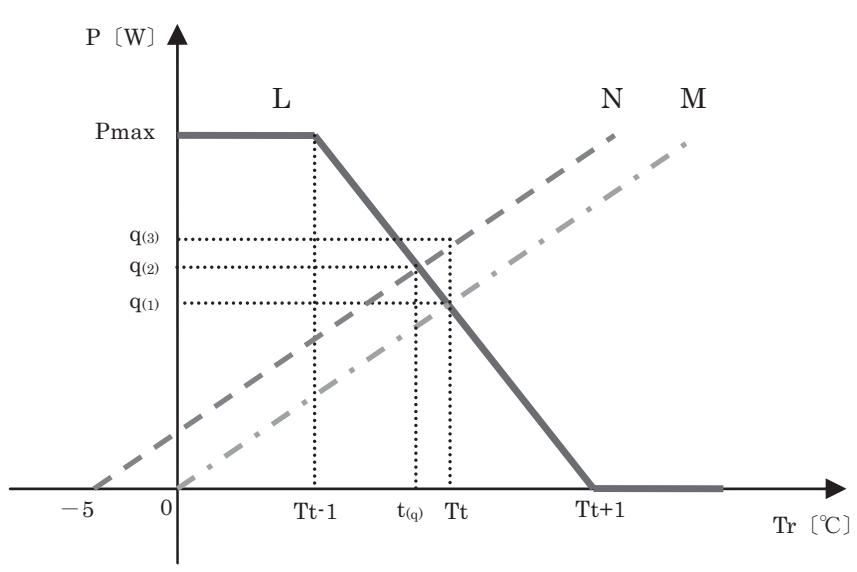

図 1 外気温度の変動によるオフセット

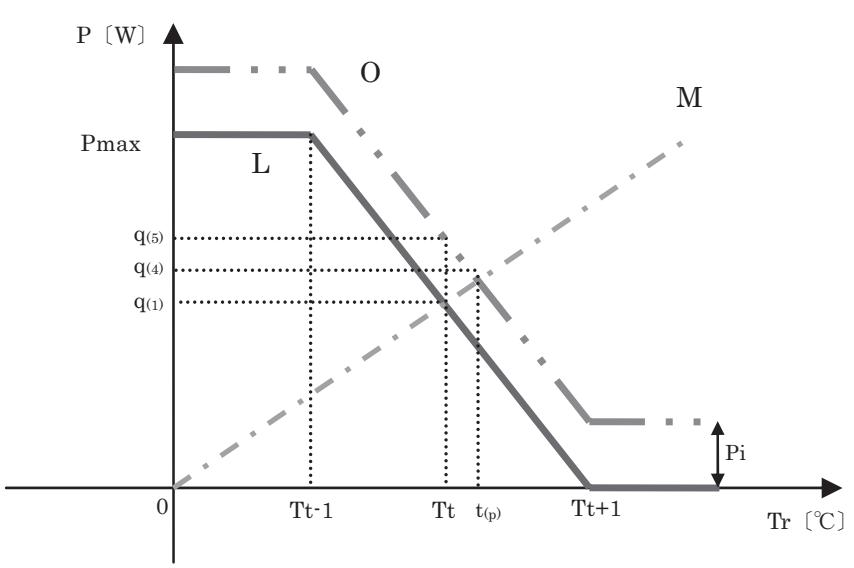

図 2 内部発熱の変動によるオフセット

熱とする。また、内部発熱は即時室温に還元されるものとする。 実験モデルにおいて、すきま風損失は無いものとし、損失熱量 $q$ は（3）式で表される。

$$
q=\overline{K S}(T r-T o) \quad \cdots(3)
$$

\section{1 外気温度の変動によるオフセット}

外気温度の変動によりオフセットが発生するメカニズムを示す。 図 1 では外気温度が下がった場合に発生するオフセットについて示 している。

外気温度 $T o\left[{ }^{\circ} \mathrm{C}\right]$ が $0\left[{ }^{\circ} \mathrm{C}\right]$ の場合において損失熱量は図 1 の直 線 M で表される。また、外気温度 To $\left[{ }^{\circ} \mathrm{C}\right]$ がー5 $\left[{ }^{\circ} \mathrm{C}\right]$ の場合にお いて損失熱量は図 1 の直線 N で表される。直線 M から直線 N に状態 変化した場合、目標室温における損失熱量は $\mathrm{q}_{(1)}$ から $\mathrm{q}_{(3)}$ になる。取 得熱量のプロファイルは直線 L 上で表されるため、室温は取得熱量 と損失熱量が均衡する $\mathrm{t}_{(\mathrm{q})}$ で安定し、オフセット $e(\infty)$ が発生する。 発生するオフセット $e(\infty)$ は次式で表される。

$e(\infty)=T t-t(q)$

同様に外気温度が上がった場合には、室温は目標室温より高い温 度で安定して、オフセットが発生する。

（1）式における比例今゙イン $K p$ を大きくしていくと直線 Lにおけ る勾配は急になり、オフセットは小さくなる。しかし、 $K p$ を大き くしていくとオフセットは小さくなるが制御系が徐々に不安定にな 
り、場合により室温は不安定になる ${ }^{23)}$ この理由により、 $K p$ を大

きくすることには限界があると言える。

\section{2 内部発熱の変動によるオフセット}

内部発熱の熱取得によりオフセットが発生するメカニズムを図 2 に示す。

対象室において内部発熱 $P i$ が無い状態、すなわち $P i=0$ から $P i$ が発生し増加した場合、Pi の増加は取得熱となり、 その取得された熱量を示寸直線 L は直線 0 に状態変 化する。室温は取得熱量と損失熱量が均衡する $\mathrm{t}_{(\mathrm{p})}$ で安定し、オフセット $e(\infty)$ が発生する。発生するオ フセット $e(\infty)$ は (5) 式で表される。

$e(\infty)=T t-t_{(p)}$

すなわち、内部発熱が増加し目標室温における取 得熱量が増加した場合には、室温は目標室温より高い温度で安定す ることになる。

また、 $K p$ を大きくしていった場合は、前節に示寸場合と同様に室 温が不安定となる。

\section{3. 制御システムによる検証}

\section{1 制御システムのモデル化}

本実験における床暖房の制御システムをブロック線図により示す。 比例制御及び比例積分制御を用いたフィードバック系制御モデルを 図 3、図 4 に示す。

次に各要素について説明する。

$X(s)$ は入力信号の時間関数 $x(t)$ をラプラス変換したものである。 本研究では入力信号とは一定值となる目標室温である。そのため、 $x(t)$ はステップ関数 $u(t)$ を用いて（6）式で表す。

$x(t)=a \cdot u(t)$

$X(s)$ は（6）式をラプラス変換し、（7）式で表される。 $X(s)=a / s \quad \cdots(7)$

$Y(s)$ は室温を示す出力信号の時間関数をラプラス変換したもの である。

制御対象の伝達関数 $G(s)$ は直接求めることが困難であるため、本 実験ではプロセス反応曲線により近似的に表す。プロセス反応曲線 を（8）式に示す。

$G(s)=K \cdot e^{-L s} / 1+T \cdot s$

比例制御の制御值 $m_{1}(t)$ は（9）式で表される。

$m_{1}(t)=K p \cdot e(t)+Q \quad \cdots(9)$

ここで、バイアス $Q$ のラプラス変換を $Q(s)$ とする。 $Q$ は任意定 数によるステップ入力なので $Q(s)$ は（10）式により表される。

$Q(s)=Q / s \quad \cdots(10)$

（9）式をラプラス変換すると（11）式が得られる。

$M_{1}(s)=K p \cdot E(s)+Q(s)$

比例積分制御の制御值 $m_{2}(t)$ は（12）式で表される。

$m_{2}(t)=K p \cdot\left\{e(t)+1 / T_{I} \int e(t)\right\}+Q$

比例制御と同様に $Q$ を（10）式で定義し、（12）式をラプラス変 換すると（13）式が得られる。

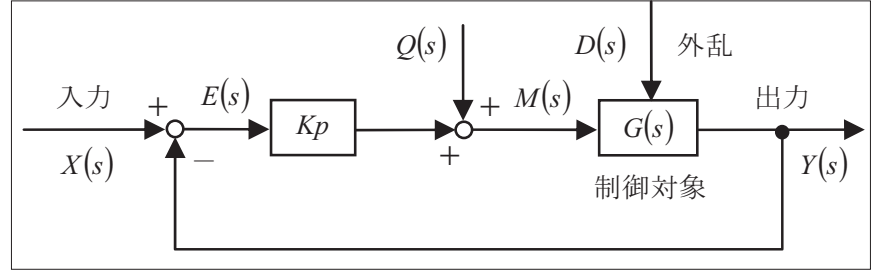

図 3 比例制御を用いた PTC 実験の制御系のモデル

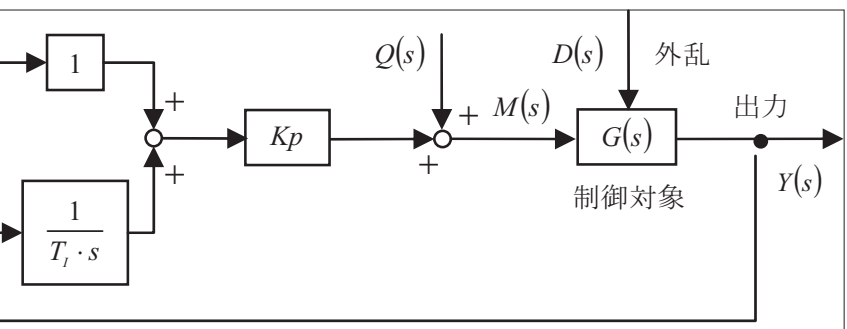

図 4 比例積分制御を用いた PTC 実験の制御系のモデル

$M_{2}(s)=K p \cdot E(s)+K p \cdot 1 / T_{I} \cdot s \cdot E(s)+Q(s)$

次に外乱となる $D(s)$ について説明する。本研究における制御系を 乱す外乱 $D(s)$ は前章で示したように、外気温度及び内部発熱の変動 に伴う加熱負荷の変動のことである。この外乱は制御対象に作用す る不規則外乱である。不規則外乱は関数により表記することが出来 ないため、不定数 $d$ を用いたステップ入力とし（14）式で表す。 $D(s)=d / s \quad \cdots(14)$

\section{2 オフセットの算定}

図 3、図 4 に示寸制御系を用いて比例制御及び比例積分制御にお けるオフセット $e(\infty)$ を算出する。図 3、図 4 に示寸制御系では $E(s)$ は（15）式で表される。

$E(s)=X(s)-Y(s) \quad \cdots(15)$

オフセット $e(\infty)$ は極限值の定理より（16）式で表される。

$$
\begin{aligned}
& e(\infty)=\operatorname{Lim}_{t \rightarrow \infty} e(t)=\operatorname{Lim}_{s \rightarrow 0} s \cdot E(s) \quad \cdots(16) \\
& \text { このオフセットの検証法について、本節で述べる。 }
\end{aligned}
$$

\section{2.1 比例制御のオフセットについての検証}

図 3 に示寸比例制御系におけるオフセット $e(\infty)$ を算出する。

図 3 に示寸比例制御系における各要素の関係より（17）式が得ら れる。

$Y(s)=G(s)\{K p \cdot E(s)+Q(s)+D(s)\} \quad \cdots(17)$

（15）式に（17）式を代入し $E(s)$ で整理すると（18）式が得られ る。

$$
\begin{aligned}
& E(s)=1 / 1+K p \cdot G(s)\{X(s)-G(s) \cdot Q(s)-G(s) \cdot D(s)\} \quad \cdots(18) \\
& \text { ここで } e(\infty) \text { は (16) 式に（18) 式を代入することにより（19）式 }
\end{aligned}
$$
で表される。

$$
\begin{aligned}
e(\infty) & =\operatorname{Lim}_{s \rightarrow 0} s \cdot E(s) \\
& =\operatorname{Lim}_{s \rightarrow 0} s \cdot[1 / 1+K p \cdot G(s)\{X(s)-G(s) \cdot Q(s)-G(s) \cdot D(s)\}]
\end{aligned}
$$

（19）式の $X(s) 、 G(s) 、 Q(s) 、 D(s)$ に（7）（8）（10）（14）式を それぞれ代入すると（20）式が得られる。 
$e(\infty)=\operatorname{Lim}_{s \rightarrow 0} s \cdot[1 / 1+K p \cdot G(s)\{X(s)-G(s) \cdot Q(s)-G(s) \cdot D(s)\}]$

$=1 / 1+K p \cdot K\{a-K(Q+d)\}$

比例制御では $e(\infty)$ が残ることが明らかになった。

\section{2.2 比例積分制御のオフセットについての検証}

図 4 に示寸比例積分制御系における各要素の関係より（21）式が 得られる。

$Y(s)=G(s)\left\{K p \cdot\left(1+1 / T_{I} \cdot s\right) \cdot E(s)+Q(s)+D(s)\right\}$

（15）式に（21）式を代入し、E $(s)$ で整理すると（22）式が得ら れる。

$E(s)=\frac{1}{1+K p \cdot\left(1+1 / T_{I} \cdot s\right) \cdot G(s)}\{X(s)-G(s) Q(s)-G(s) D(s)\}$

ここで、 $e(\infty)$ は（16）式に（22）式を代入することにより 式で表される。

$$
\begin{aligned}
e(\infty) & =\operatorname{Lim}_{s \rightarrow 0} s \cdot E(s) \quad \cdots(23) \\
& =\operatorname{Lim}_{s \rightarrow 0} s \cdot\left[\frac{1}{1+K p \cdot\left(1+\frac{1}{T_{I} \cdot s}\right) \cdot G(s)}\{X(s)-G(s) \cdot Q(s)-G(s) \cdot D(s)\}\right]
\end{aligned}
$$$$
\text { （23）式に } X(s) 、 G(s) 、 Q(s) 、 D(s) \text { を（7）（8）（10）（14）式か }
$$

ら（23）式にそれぞれ代入すると（24）式が得られる。

$e(\infty)=\operatorname{Lim}_{s \rightarrow 0} s \cdot\left[\frac{1}{1+K p \cdot\left(1+\frac{1}{T_{I} \cdot s}\right) \cdot G(s)}\{X(s)-G(s) \cdot Q(s)-G(s) \cdot D(s)\}\right]$ $=0$ (24)

比例積分制御では $e(\infty)$ がゼロになることが明らかになった。

\section{4. 実験による検証}

\section{1 実験モデルと計測手法}

本研究では模型実験により、PTC ヒーターを用いた電気床暖房に よる比例積分制御におけるオフセット除去の有效性を検証している。 人工気象室内に実験モデル（床面積: $3.6 \mathrm{~m}^{2}$ 、天井高: $1.2 \mathrm{~m}$ ）を設 置した。人工気象室内を屋外と想定して実験を行った。表 1 に実験 モデルの概要及び使用する PTC ヒーターの概要を示す。図 5 に実験 モデル断面、図 6 に実験モデルの床の断面構成を示す。予備実験よ り算出された実験モデルの熱損失係数は $2.2\left[\mathrm{~W} / \mathrm{m}^{2} \cdot \mathrm{K}\right]$ であった。 温度、湿度、熱流量、PTC ヒーターの消費電力量を 10 秒間隔で計測 する。

\section{2 実験内容}

外気温度、内部発熱の条件により時系列変動する 5 つの加熱負荷 条件を作成し、On-Off 制御、比例制御、比例積分制御を行った。表 2 に実験ケースについて示す。制御目標は全て室温（床面上方 $600 \mathrm{~mm}$ 位置の温度) $21.5\left[{ }^{\circ} \mathrm{C}\right]$ と寸る。気象条件として「0 [ $\left.{ }^{\circ} \mathrm{C}\right]$ 一定」「一 $\left[{ }^{\circ} \mathrm{C}\right]$ 一定」の場合と、図 7 に示寸他 3 種類の変化する気象条件を用 いる。外気温度の影響や内部発熱によって実験模型内に冷房負荷が 発生しないように図 8 に示寸 3 パターンのスケジュールに基づいて 内部発熱を行った。
表 1 実験モデル概要

\begin{tabular}{|c||c|}
\hline 模型寸法 (内法) & $1.9 \times 1.9 \times 1.2[\mathrm{~m}]$ \\
\hline 床面積 & $3.61\left[\mathrm{~m}^{2}\right]$ \\
\hline 床暖房敷設面積 & $3.24\left[\mathrm{~m}^{2}\right]$ \\
\hline 室容積 & $4.33\left[\mathrm{~m}^{2}\right]$ \\
\hline 床暖房敷設率 & $89.75 \%$ \\
\hline PTCヒーター寸法 (1枚) & $900 \times 900 \times 0.5[\mathrm{~mm}]$ \\
\hline PTCヒーター最大電流 (1枚) & $5.0[\mathrm{~A}]$ \\
\hline PTCヒーター安定電流 (1枚) & $0.75 \sim 1.5[\mathrm{~A}]$ \\
\hline PTCヒーター安定消費電力 (1枚) & $75 \sim 150[\mathrm{~W}]$ \\
\hline
\end{tabular}

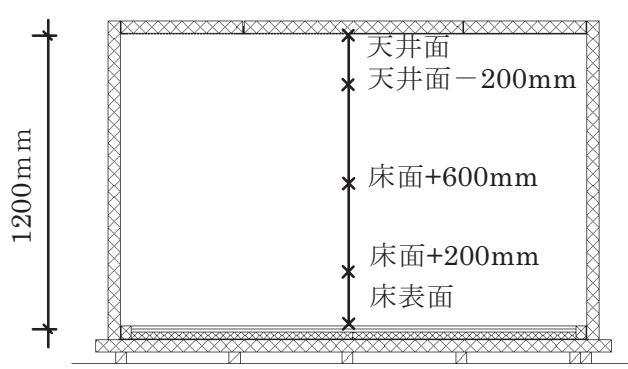

図 5 実験モデル断面

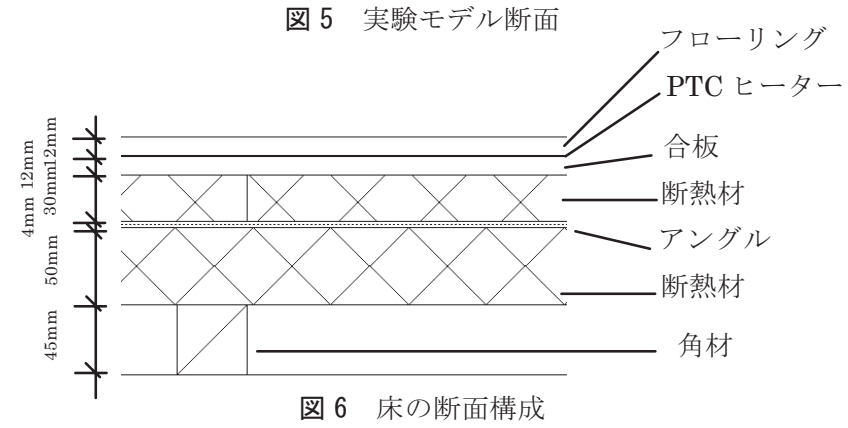

\begin{tabular}{|c|c|c|c|c|c|c|}
\hline & On-Off制御 & 比例制御 & 比例積分制御 & 制御対象 & 気象条件 & 内部発熱 \\
\hline \multirow{5}{*}{ Case No. } & $0-1$ & $1-1$ & $2-1$ & \multirow{5}{*}{$\begin{array}{l}\text { 室温 } 21.5^{\circ} \mathrm{C} \\
\text { (床上方 } 600 \mathrm{~mm} \\
\text { 位置の温度) }\end{array}$} & 1 & 1 \\
\hline & & $1-2$ & $2-2$ & & 2 & 1 \\
\hline & & $1-3$ & $2-3$ & & 3 & 2 \\
\hline & & $1-4$ & $2-4$ & & 4 & 1 \\
\hline & & $1-5$ & $2-5$ & & 5 & 3 \\
\hline
\end{tabular}

表 2 実験ケース

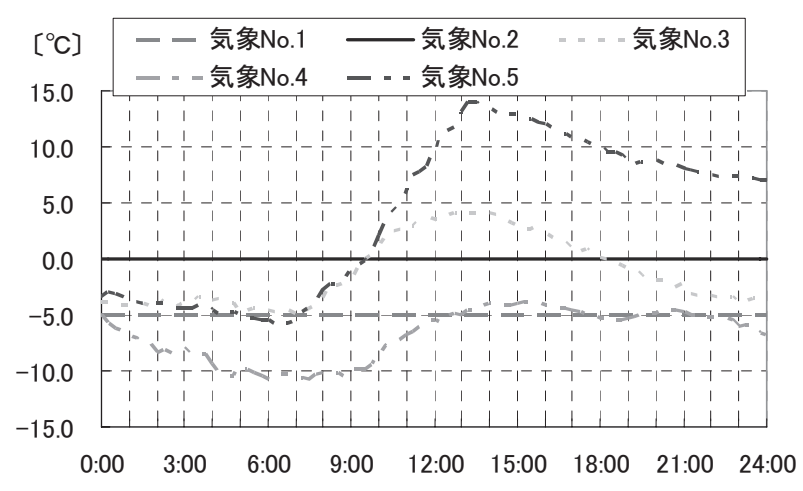

図 7 気象条件

\section{3 限界感度法による制御式の決定}

比例制御および比例積分制御においては比例ゲイン、積分時間の 適切な值を選ぶ必要がある。本研究における実験では、これらの值 はジーグラー・ニコルスの限界感度法によって決定した。以下に予 備実験を行い限界感度法により算出した制御式を示す。 
比例制御

$$
\begin{aligned}
& M V=K p \times e_{n}+Q \\
& K p=71.5 \quad Q=50
\end{aligned}
$$

比例積分制御

$$
\begin{gathered}
M V_{n}=K p\left(e_{n}+\frac{\theta}{T_{I}} \sum e_{n}\right)+Q \quad \cdots(26) \\
K p=64.4 \quad \theta=10 \quad T_{I}=1155 \quad Q=50
\end{gathered}
$$

なお、On-Off 制御における実験では、目標温度帯を $21.5 \pm 1.0\left[{ }^{\circ} \mathrm{C}\right]$ とし、目標温度帯における上限值で電力投入を止め、下限值で電力 投入を始めるといったプロセスを繰り返す On-Off 制御により実験 を行った。

\section{5. 検証結果}

本研究における実験では 5 つの加熱負荷条件を作成し、比例積分 制御によるオフセットの除去の有効性の検討のほか、On-Off 制御、 比例制御、比例積分制御の比較による検討を行った。どの制御方法 が優れているかを制御成績により評価した。制御成績は偏差の二乗 和より求められる。制御成績 $I_{e}$ は $(27)$ 式より求められる。

$$
I_{e}=\int e(t)^{2} d t
$$

ここで、偏差は時間により変動するものであることから $e(t)$ と表 されるが、本研究では偏差を離散化された数值 $e_{n}$ を用い、 $I_{e}$ を以 下の（28）式とした。

$$
I_{e} \approx \sum e_{n}{ }^{2}
$$

一般に $I_{e}$ の值が小さい場合、よい制御成績とされている。実験 Case 0-1〜Case2-5 における制御成績による評価および変動係数、平 均室温、室温の分散、最高室温、最低室温、消費電力量の実験結果 を表 3 に示す。また、加熱負荷条件が同じである実験 Case $0-1$ と Case1-1 と Case2-1、Case1-5 と Case2-5 それぞれの室温の変化を図 9、図 10 に示す。

比例制御と比例積分制御の比較として 5 つの加熱負荷条件に対し、 実験 Case2-1 以外では比例積分制御の制御成績の方が小さい值を示 した。このことから比例積分制御の方が制御として優れていると言 える。また、検定統計量 T を求め、帰無仮説『平均室温と目標温度 は等しい』を対立仮説『平均室温と目標温度は等しくない』に対し て、有意水準 5\%で両側検定を行ったところ、比例制御の実験におけ る帰無仮説はすべて茟却されたのに対し、比例積分制御における帰 無仮説は寸べて棄却されなかった。これにより、比例積分制御によ るオフセットの除去の有効性が明らかとなったと考える。

実験 Case1-1 と Case2-1、Case1-4 と Case2-4 の制御成績がそれぞ れ近い值を示している理由は、加熱負荷の急激な変動が比例積分制 御において室温を一時的に振動させ、その振動が収まる前に、次の 加熱負荷の変動が起きて制御が安定しないためである。内部発熱ス ケジュールの条件 1 のように頻繁に加熱負荷が変化するような場合 は比例積分制御における制御成績が大きくなってしまう。

比例制御に積分（I）動作を加えた比例積分制御を行ったところ、 オフセットは除去された。ここで、室温の急激な変動は見られず、 微分（D）動作の比例項目である偏差も少ないことから、微分動作を 省くことが出来ることが明らかとなった。そこで、比例積分制御を
条件 1

\begin{tabular}{|c|c|c|c|c|c|c|c|c|}
\hline $\begin{array}{l}\text { 実験 } \\
\text { Case }\end{array}$ & 制御式 & 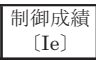 & \begin{tabular}{|c|} 
変動係数 \\
{$[\%]$}
\end{tabular} & \begin{tabular}{|c|} 
平均聜温 \\
{$\left[{ }^{\circ}\right]$}
\end{tabular} & 分散 & 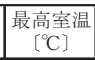 & 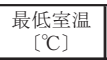 & $\begin{array}{c}\text { 消費電力量 } \\
\text { Wh }\end{array}$ \\
\hline $0-1$ & 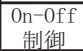 & 1143.99 & 4.10 & 21.83 & 0.80 & 23.50 & 20.22 & 3739.7 \\
\hline 1-1 & \multirow{5}{*}{ 比例制御 } & 71.68 & 1.04 & 21.60 & 0.05 & 22.62 & 20.98 & 3698.0 \\
\hline $1-2$ & & 149.10 & 1.30 & 21.71 & 0.08 & 22.85 & 21.18 & 2904.6 \\
\hline 1-3 & & 79.30 & 0.92 & 21.66 & 0.04 & 22.30 & 21.30 & 3090.2 \\
\hline $1-4$ & & 74.72 & 1.07 & 21.58 & 0.05 & 22.63 & 21.05 & 3953.6 \\
\hline 1-5 & & 89.11 & 0.80 & 21.71 & 0.03 & 22.10 & 21.40 & 2448.7 \\
\hline $2-1$ & \multirow{5}{*}{$\begin{array}{l}\text { 比例積分 } \\
\text { 制恠 }\end{array}$} & 72.56 & 1.14 & 21.52 & 0.06 & 22.38 & 20.30 & 3671.4 \\
\hline $2-2$ & & 78.54 & 1.14 & 21.55 & 0.06 & 22.65 & 20.87 & 2882.8 \\
\hline $2-3$ & & 45.86 & 0.93 & 21.50 & 0.04 & 22.08 & 20.87 & 3070.9 \\
\hline $2-4$ & & 70.76 & 1.14 & 21.53 & 0.06 & 22.58 & 20.60 & 4625.8 \\
\hline $2-5$ & & 10.01 & 0.47 & 21.50 & 0.01 & 21.92 & 21.10 & 2409.2 \\
\hline
\end{tabular}
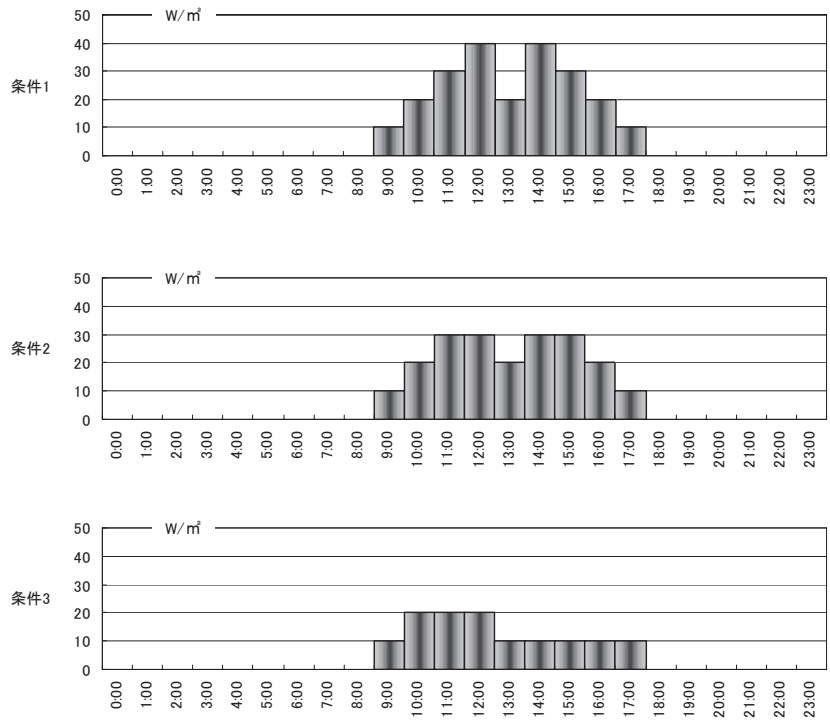

図 8 内部発熱スケジュール

表 3 実験結果（3:00～23:59）

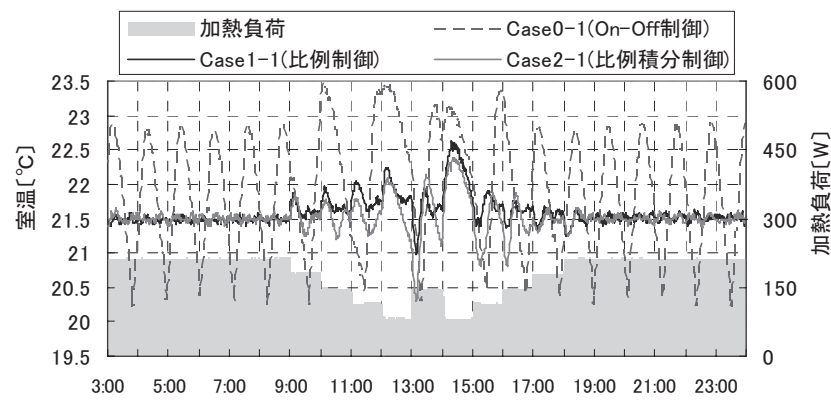

図 9 Case0-1, Case1-1, Case2-1 室温の変化（3:00～23:59）

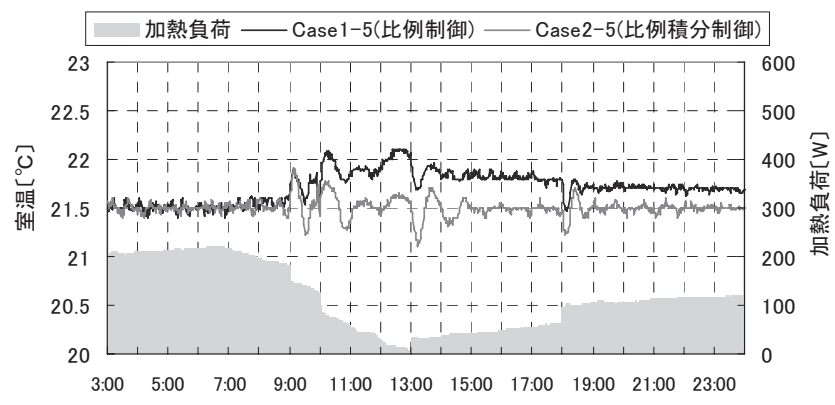

図 10 Case1-5, Case2-5 室温の変化（3:00～23:59）

最終の制御モデルとした。 


\section{6. まとめ}

本研究では PTC ヒーターを住宅の床暖房として適用する場合のオ フセット除去の有効性を検証するために模型実験を行った。PTC ヒ ーターを用いた電気床暖房を制御し、異なる加熱条件に対し、On-Off 制御、比例制御、比例積分制御を用いて、その有効性について主に オフセットの除去の観点から検討を行った。結果、以下のことが明 らかとなった。

本研究により、目標であった比例積分制御によるオフセットの除 去は達成され、PTC ヒーターによる住宅の床暖房の制御方法の一つ として位置づけられるものであることを明らかにした。

本研究の今後の課題は、実用規模の住宅に適用し、制御モデルの 信頼性を高めていくことである。

\section{謝辞}

本研究は電気床暖房工業会の協力を得て実施した。ここに記して 感謝の意を表す。

記号

2 章

$e:$ 偏差 $\left[{ }^{\circ} \mathrm{C}\right]$ (本研究における偏差は $\pm 1\left[{ }^{\circ} \mathrm{C}\right]$ 幅とする)

$e(\infty):$ オフセット $\left[{ }^{\circ} \mathrm{C}\right]$

$K p:$ 比例ゲイン $\left[\% /{ }^{\circ} \mathrm{C}\right]$

$\overline{K S}$ : 総合熱貫流率 $[W / K]$

直線 $L$ : 比例制御を用いた $P T C$ ヒーターの発熱量のプロファイル

直線 $M$ : 外気温度 $0\left[{ }^{\circ} \mathrm{C}\right]$ における損失熱量のプロファイル

$M V:$ 制御值 $[\%]$

直線 $N$ : 外気温度 $\left.-5{ }^{\circ} \mathrm{C}\right]$ における損失熱量のプロファイル

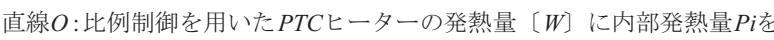
加えた発熱量のプロファイル

$P$ :発熱量 $[W]$

$P \max : P T C$ ヒーターの最大発熱量 $[W]$

$P i$ : 内部発熱量 $[W]$

$q$ : 損失熱量 $[W]$

$Q p:$ バイアス $[\%]$

$q(1)$ 外気温度 $0\left[{ }^{\circ} \mathrm{C}\right]$ の場合の目標室温 $T t\left[{ }^{\circ} \mathrm{C}\right]$ における損失熱量 $[W]$

$q(2)$ : 外気温度 $-5\left[{ }^{[0} \mathrm{C}\right]$ の場合の室温 $t(q)\left[{ }^{\circ} \mathrm{C}\right]$ における損失熱量 $[W]$

$q(3)$ : 外気温度 $-5\left[{ }^{\circ} \mathrm{C}\right]$ の場合の目標室温 $T t\left[{ }^{\circ} \mathrm{C}\right]$ における損失熱量 $[W]$

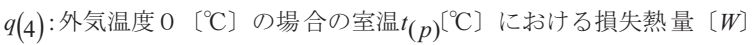

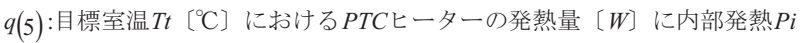
$[W]$ を足した発熱量 $[W]$

To : 外気温度 $\left[{ }^{\circ} \mathrm{C}\right]$

$\mathrm{Tr}$ : 室温 $\left[{ }^{\circ} \mathrm{C}\right]$

$T t$ :目標室温 $\left[{ }^{\circ} \mathrm{C}\right]$

\section{3 章}

$a$ : 任意定数(本実験における目標室温)

$D(s)$ :外乱要素のラプラス変換

$d:$ 外乱要素

$E(s)$ : 偏差のラプラス変換

$e(t)$ : 偏差

$e(\infty):$ オフセット

$G(s)$ :制御対象の伝達関数

$K:$ ゲイン
$K p:$ 比例ゲイン

$L:$ 無䭾時間

$M(s)$ : 制御值のラプラス変換

$M_{1}(s)$ : 比例制御の制御值のラプラス変換

$M_{2}(s)$ : 比例積分制御の制御值のラプラス変換

$m_{1}(t)$ : 比例制御の制御値

$m_{2}(t):$ 比例積分制御の制御値

$Q:$ バイアス

$Q(s)$ :バイアスのラプラス変換

$T$ : 時定数

$T_{I}:$ 積分時間

$u(t):$ ステップ関数

$X(s)$ : 入力関数のラプラス変換

$x(t):$ 入力関数

$Y(s)$ :出力関数のラプラス変換

\section{4 章}

$e_{n}:$ 偏差 $\left[{ }^{\circ} \mathrm{C}\right]$

$K p$ : 比例ゲイン $\left[\% /{ }^{\circ} \mathrm{C}\right]$

$M V_{n}$ : 制御值 [\%]

$Q:$ バイアス $[\%]$

$T_{I}$ : 積分時間〔秒〕

$\theta$ : 制御間隔〔秒〕

5 章

$e_{n}:$ 偏差 $\left[{ }^{\circ} \mathrm{C}\right]$

$e(t)$ : 時刻 $\mathrm{t}$ における偏差 $\left[{ }^{\circ} \mathrm{C}\right]$

$I_{e}:$ 評価関数

\section{参考文献}

1)譚洪衛ほか, 床暖房の快適性に関する研究, 空気調和衛生工学会学術講演会講 演論文集，pp. 1125-1228，1990．10

2）新堀喜則ほか，暖房時の室内温熱環境と快適性に関する実験研究，日本建築学 会大会学術講演梗概集，D 分冊，pp. 677-678，1988．10

3) 三垣拓郎 浅野良晴, $\mathrm{OA}$ フロア用潜熱蓄熱式床暖房と対流式空調機の併用運転 時の室温制御に関する研究, 日本建築学会大会学術講演梗概集, D-2 分冊, pp. 935-936, 1998 . 9

4) 稲葉祐輔 浅野良晴 高村秀紀, SET*の時系列変化を考慮した潜熱・㩆熱蓄熱材 併用型電気床暖房の予測制御に関する研究：その 3 日射の影響下における SET* を指標とした投入熱量の予測制御，日本建築学会環境系論文集，№.621，pp. $45-50,2007.11$

5) 稲葉祐輔 浅野良晴 高村秀紀, 特別養護老人ホームにおける影熱・潜熱蓄熱材 併用型電気床暖房の性能伻価に関する研究：その 1 シミュレーションによる日 射取得熱量の把握と実測結果，日本建築学会大会学術講演梗概集，D-2 分冊， pp. $287-288,2006.7$

6) 浜口和久 浅野良晴 三坦拓郎 三島真巳 岸本孝志， $\mathrm{T}$ 事務所における床暖房 と空調の併用運転の性能伻価に関する研究：(その 1) 床暖房運転時の実態調查, 日本建築学会大会学術講演梗概集, D-2 分冊, pp. 1025-1026，1999．9

7) 三浦尚志 澤地孝男 堀褾治 細井照憲, 定常状態における温水床暖房のエネ ルギー消費量の推定法, 日本建築学会大会学術講演梗概集, D-2 分冊, pp. $1149-1150,2006.9$

8）吉浦温雅 志賀均 濱砂ひとみ 水沼信 福代和宏 中園眞人，温水式床暖房 による自然刘流温度分布における模型実験，日本建築学会大会学術講演梗概集， D-2 分冊， pp. 153-154，2005．9 
9) 小林幹彦 江頭満 齋藤恭子 新谷紀雄, PTC 特性を持つ面状発熱体の開発, 日本機械学会大会講演論文集, pp. 459-460，2003。8

10) 占部亘 志村欣一 宮永俊之, PTC 床暖房の実測による正温度特性の推定, 日 本建築学会大会学術講演梗概集, D-2 分冊, pp. 1197-1198, 2007 .8

11) 尾形和哉 藤井省三 加藤典彦 松村司郎, 発電ボイラにおける過熱蒸気温度 の適応制御に関する考察，日本機械学会論文集（C編），pp. 111-118，1991.7

12) 藤井公平 横田勇司 竹澤聡, PID 制御による公配条件化における低速定常走行 に関寸る研究，日本機械学会大会講演論文集，pp. 53-54，2006．9

13）李耕 川崎晴久, サーボ制御系のモータパワーを考慮した PID ゲイン自動調整 の研究, 日本機械学会論文集（C編），pp. 92-98，2003．6

14) 川田和男 十河宏行 山本透 間田泰弘, セルフチューニング PID 制御法によ るクレーンのつり荷の振れ止め制御，日本機械学会論文集 (C 編) , pp. 115-122， 2005 . 2

15) 森田譲 前田保憲 日隈崇文 , ニューラルネットワークによる倒立振子制御に おけるPID ゲインのセルフチューニング, 日本知能情報ファジイ学会誌, Vol. 16 , No. 3 , pp. 262-270 (2004)

16) Kasahara, M., T. Yamazaki, Y. Kuzuu, Y. Hashimoto, K. Kamimura, T. Matsuba, S. Kurosu. 2001. Stability analysis and tuning of PID controller in VAV system. ASHRAE Transaction 107(1):285-296.

17) Kasahara, M., T. Yamazaki, Y. Kuzuu, Y. Hashimoto, K. Kamimura, T. Matsuba, S. Kurosu. 1999. Design and tuning of robust PID controller for HVAC system. ASHRAE Transaction 105(2) :154-166.

18）國吉敬司 赤司泰義, PID パラメータの設定不全が空調システム性能に与える影 響の検証と最適調整法の提案，日本建築学会環境系論文集，No. $610 ， p p$
$59-65,2006.12$

19）前原勝樹 相楽典泰 宋城基, VAV 空調システム制御パラメータの最適化に関す る研究, 日本建築学会環境系論文集, No. 603, pp. 63-70, 2006 . 5

20）松岡一平 吉田治典 村井大介，シミュレーションを用いた空調制御システム のコミッショニング , 日本建築学会大会学術講演梗概集, D-2 分冊, pp. 1041-1042 , 2001 . 9

21) 丹羽英治 渡邊剛 中原信生 VAV 空調システムにおける制御パラメータの設定 不全がシステムの動特性に及ぼす影響とその最適調整法に関する研究，日本建 築学会計画系論文集, No. 477 , pp. 19-28，1995。11

22）宮崎誠一 宮崎仁，パソコンで学ぶ自動制御の応用学 モーター制御からアド バンスト制御までを実験する，CQ出版，1992

23）宮崎誠一 宮崎仁，パソコンで学ぶ自動制御の実用学 PID 制御/ディジタル制 御技術を基礎から実験する，CQ出版，1991

24）システム制御情報学会編, PID 制御, 朝倉書店, 1992

25）山本重彦 加藤尚武, PID 制御の基礎と応用, 朝倉書店, 1997

26) 藤井澄二ほか, 制御工学, 東京電気大学出版局, 1985

27) 椹木義一 添田喬, わかる制御工学, 日新出版, 1966

28）石井次郎，技術者のための自動制御入門，日本理工出版会，1995

29）江口弘文，初めて学ぶPID 制御の基礎，東京電気大学出版局，2006

30) 杉江俊治 藤田政之，フィードバック制御入門，コロナ社，1999

31）水上憲夫，自動制御，朝倉書店，1968

32）樋口龍雄, 自動制御理論, 森北出版株式会社, 1989

（2008年12月10日原稿受理，2009年 4 月30日採用決定） 